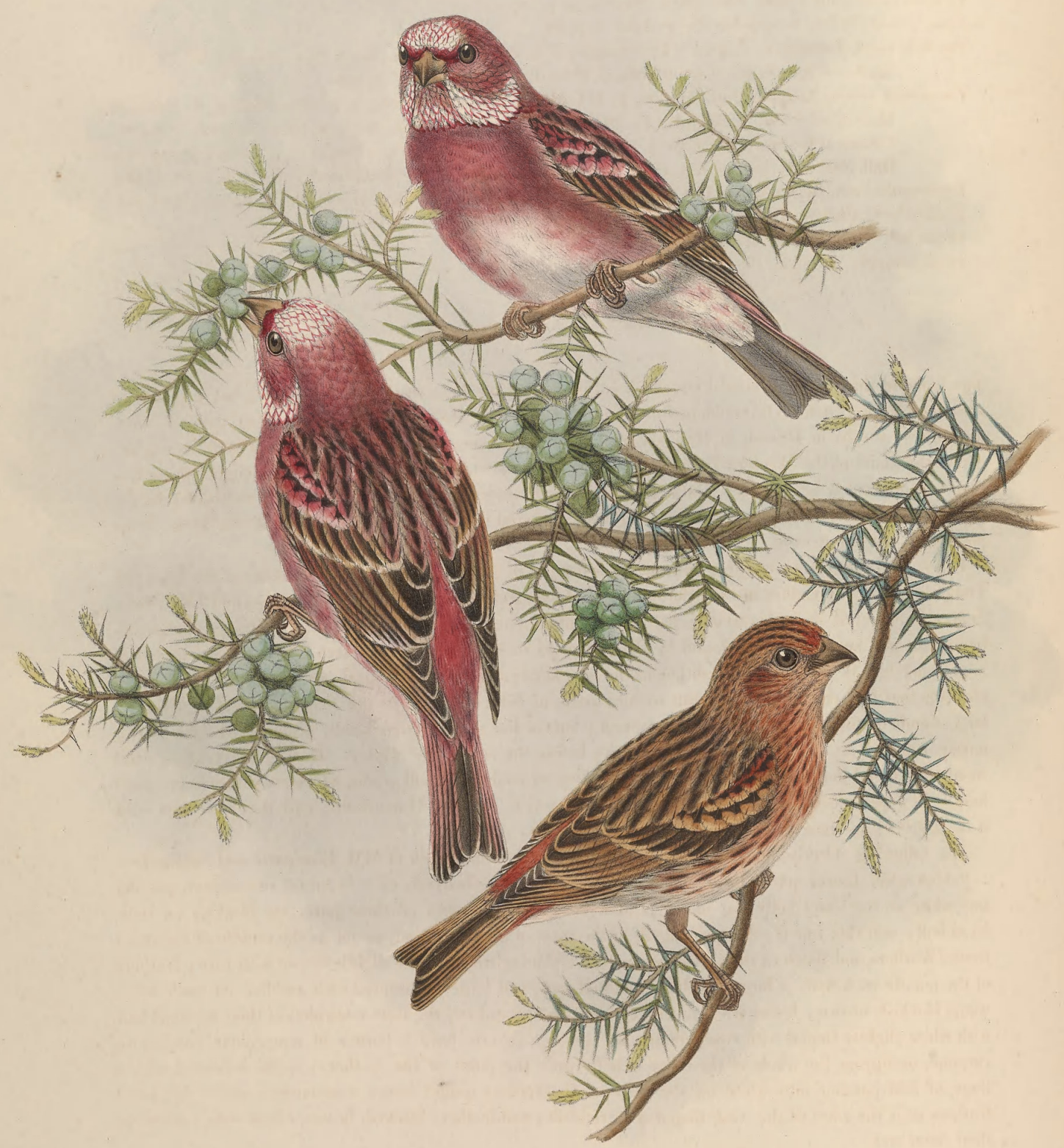




\title{
CARPODACUS ROSEUS.
}

\author{
Rosy Grosbeak.
}

Fringilla rosea, Pallas, Reise Russischen Rheichs, iii. p. 699.

Passer roseus, Pallas, Zoographia Rosso-Asiat. ii. p. 23.

Pyrrhula rosea, Temminck, Manuel d'Ornithologie, i. p. 335.-Naumann, Vögel Deutschlands, iv. Taf. 113. fig. 3.-Schrenck, Reise Amurlande, p. 295.-Radde, Sibir. Reise, p. 186.

Carpodacus roseus, Kaup, Naturl. System, p. 161.-Gray, Genera of Birds, i. p. 384.-Bonap. \& Schlegel, Monogr. Loxiens, p. 18, pls. 19, 20.-Bonap. Conspectus Gen. Av. i. p. 533.-Degland \& Gerbe, Oiseaux d'Europe, p. 157.-Gray, Hand-l. Birds, ii. p. 102.-Cordeaux, Ibis, 1875, p. 183.-Taczanowski, Bull. Soc. Zool. France, i. p. 181.-Seebohm, Ibis, 1876, p. 165.-Blakiston \& Pryor, Ibis, 1878, p. 545 Erythrospiza rosea, Bonap. Comp. List Birds Europe and N. America (1838), p. 34.-Gould, B. Europe, iii. pl. 207. Erythrothorax albifrons, Brehm, Naumannia, 1805, p. 276.

Propasser roseus, David \& Oustalet, Oiseaux de la Chine.

Uragus sibiricus, Swinhoe, Ibis, 1876 , p. 333 (err.).

The home of the present beautiful Grosbeak is Siberia and the Eastern Palæarctic region ; but it possesses considerable interest from its occidental occurrence in Europe. Bonaparte and Schlegel state that it is seen, though very rarely, in Russia, in Hungary, and even in Germany. More definite instances of its capture within the limits of the Western Palaarctic region are those which have taken place in Heligoland, no less than four specimens being in Mr. Gätke's collection. It seems to wander occasionally to the island in the autumn, two of Mr. Gätke's specimens having been captured in the month of October, all the birds in his possession being immature.

Pallas, who first discovered this bird, says that it nests in the north of Siberia on the banks of the Lena and Tungusk rivers, and winters in the willow-covered islands and desert-tracts near the Silenga and Uda rivers. Schrenck observed it in Amurland; but only in autumn, and Radde met with it in the Buraga Mountains in autumn and spring. It was found by Dr. Dybowski to be common in Eastern Siberia at the season of migration; but it does not nest either in the southern parts of Lake Baical or in Dauria. Père David observes that it is very common in the eastern parts of Siberia, and visits the neighbourhood of Pekin in large numbers towards the end of the autumn; but in the spring it has totally disappeared from China, having returned to the more northern countries before the end of the winter. During the extreme cold weather he found it established in the Isinling, feeding on seeds and small grains, which constitute its principal food. In Japan, according to Mr. Blakiston and Pryer, it is called O-mashi-ko; and they have met with it in Yezo and purchased other specimens at Tokio.

The following description of the sexes is translated from the work of MM. Bonaparte and Schlegel:-

"Adult male. Lower parts, head, neck, rump, and upper tail-coverts of a beautiful rose-colour, passing into white on the lower belly and under tail-coverts; all the plumes of these parts are blackish on their basal half; and this tint is often prolonged, in the form of a pointed spot, as far as the middle of the web; frontal feathers and those of the throat pointed, of a shining white colour slightly tinged with rose ; feathers of the mantle each with a large, blackish, pointed spot, and largely bordered with reddish on each side; wings blackish brown; lesser wing-coverts edged with rose-colour, the least margined in their terminal half with white slightly tinged with rose-colour; the greater coverts have a border of rose-colour, verging to carmine, occupying the whole of the onter web towards the point of the feathers; quills bordered with a tinge of buff passing into white on the edge of the tertiary quills; lower wing-coverts white, the small feathers near the edge of the wing tinged with reddish; tail-feathers blackish brown, edged with reddish on their outer web.

"Young female. Above olive-brown, slightly tinged with yellow on the rump, edges of the feathers of a clearer colour, passing more or less into whitish on the mantle and rump; an indistinct whitish line behind the eye ; wings and tail blackish brown passing into olivaceous grey on the outer edge of the feathers; lesser and greater wing-coverts tipped with yellowish grey; under surface white, uniform on the lower abdomen and under tail-coverts, and having on the other parts large longitudinal spots of dark olivaceous brown."

Pallas states that the plumage of the old female has everywhere a slight shade of dark rose-colour, and is a little inferior in size to the male; but this description wants the striations on the upper surface. I may have figured a young male; but, judging from the allied birds, I think I have not, and that the Plate represents two males and a female of the natural size in their finest state of plumage. 


\section{$2 \mathrm{BHL}$ Biodiversity Heritage Library}

Gould, John. 1879. "Rosy Grosbeak, Carpodacus aurantia [PI. 33]." The Birds of Asia 5(XXXI), -. https://doi.org/10.5962/p.323282.

View This Item Online: https://www.biodiversitylibrary.org/item/121124

DOI: https://doi.org/10.5962/p.323282

Permalink: https://www.biodiversitylibrary.org/partpdf/323282

\section{Holding Institution}

Smithsonian Libraries

\section{Sponsored by}

Smithsonian Institution Libraries

\section{Copyright \& Reuse}

Copyright Status: Not in copyright

This document was created from content at the Biodiversity Heritage Library, the world's largest open access digital library for biodiversity literature and archives. Visit BHL at https://www.biodiversitylibrary.org. 